\title{
Comments on the Judgement of the Court of Justice of the European Union of April 29, 2015: Is the Permanent Exclusion of MSM from Giving Blood Compatible with the Directive 2004/33/EC? What Are the Consequences for Blood Donations in Germany?
}

\author{
Bita Bakhschai $^{a}$ Stephan T. Kiessig ${ }^{b}$ \\ a Law Office Boltz, Scheller \& Colleagues, Speyer, Germany; \\ ${ }^{b}$ Ruhr-Plasma-Centre GmbH, Bochum, Germany
}

The Court of Justice of the European Union stated in its judgement of April 29, 2015 in Case C-528/13 (Geoffrey Léger v Ministre des Affaires sociales, de la Santé et des Droits des FEMMES, établissement français du sang) [1] that the permanent deferral from blood donation for men who have had sexual relations with another man (MSM) may be justified, having regard to the situation prevailing in the Member State concerned. It must be established whether those persons are at a high risk of acquiring severe infectious diseases, such as HIV, and that there are no effective detection techniques or less onerous methods for ensuring a high level of health protection for recipients. In the following, the legal consequences of this judgement as well as its implications for blood establishments will be discussed, particularly with regard to the situation in Germany.

1) In the context of a reference for a preliminary ruling pursuant to Article 267 of the Treaty on the Functioning of the European Union (TFEU) [2], the courts of the Member States, in disputes which have been brought before them, are allowed to refer questions to the Court of Justice about the interpretation of European Union law or the validity of a European Union act. The Court of Justice does not decide the dispute itself. It is for the national court of the Member States to dispose of the case in accordance with the European Union Court's decision. The European Union Court's decision is similarly binding on other national courts before which a similar issue is raised [3].

2) Moreover, it is recommended that the Court of Justice rulings are respected and properly implemented by the Member
State. Otherwise a formal infringement procedure pursuant to Article 258 TFEU may be initiated by the European Commission. Therefore, each Member State should verify unambiguously whether the permanent deferral from blood donation for MSM is justified.

Due to different epidemiological situations in Member States, the implementation of the Court's judgement may lead to differences within the European Union. There might be Member States with a permanent deferral from blood donation for MSM and other Member States with only a temporary exclusion of MSM. Therefore, the proper implementation of the Court's judgement may contribute significantly to foreclosure of a substantial part of the common market. It is likely possible that a Member State with a permanent exclusion of MSM will not accept blood or plasma donated in a Member State where only a temporary exclusion of MSM applies.

3) As a first reaction on the judgement of the court of Justice of the European Union, in November 2015 the Ministre des Affaires sociales, de la Santé et des Droits des femmes, établissement français du sang has decided to no longer exclude MSM. They will permit the donation of MSM in several stages and distinguish between the donation of whole blood and plasma [4].

In Germany, there has already been a discussion in the year 2012 of whether only a temporary exclusion of donors with sexual risk behavior might be sufficient to minimize the risk of contamination for recipients and to ensure a high level of protection of public health [5]. However, the German Medical Association (Bundesärztekammer) held that, contrary to the Federal Ministry

\section{KARGER \\ Fax +497614520714

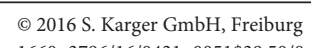


of Health (BMG) and the Paul-Ehrlich-Institut (PEI), such a provision does not comply with EU legislation. The above mentioned judgement of the Court of Justice will establish legal clarity. It can be expected that the German Medical Association in agreement with the PEI will take the judgement of the Court into account when updating the Guidelines for the Preparation of Blood and Blood Components and for the Use of Blood Components (Hemotherapy) [6]. However, as long as the German Medical Association has not yet revised the said guidelines as far as donors with sexual risk behavior are concerned, the guidelines are still valid in the current version, which determine a permanent deferral from blood donation for MSM [6, chapter 2.2.1].

4) The holder of a manufacturing authorization pursuant to section 13 German Drug Act (Arzneimittelgesetz; AMG) [7] has to ensure that the manufacture or the testing of the medicinal products is carried out according to the latest standards prevailing in science and technology, and in the procurement of blood and blood components, additionally, according to the provisions contained in Part Two of the German Transfusion Act (Transfusionsgesetz; TFG) [8, section 14 subsection 1 number 6 a].

The guidelines of the German Medical Association are partially based on Part Two of the TFG [8] and define the generally acknowledged state of medical science and technology $[8$, section 12a]. Therefore, the holder of a manufacturing authorization has to ensure that the procurement of blood is carried out in compliance with the Guidelines of the German Medical Association in its current version.

The same applies to the physician in charge pursuant to section 4 sentence 1 number 2 TFG or the physician who is present when the withdrawal procedure is carried out on a donor pursuant to section 4 sentence 1 number 3 TFG.

5) From the point of view of the qualified person pursuant to section 14 AMG the main topic of the decision of the European Court of Justice is not discrimination but safety of blood and blood products. Despite of the decision of the European Court of Justice, there is still the responsibility of the qualified person pursuant to section 14 AMG and the physician in charge pursuant to section 4 sentence 1 number 2 TFG (hereinafter medical head) or the physician who is present when the withdrawal procedure is carried out on a donor in a blood establishment pursuant to section 4 sentence 1 number 3 TFG (hereinafter physician).

The medical head, or the physician, has to possess the necessary professional knowledge according to the state of the medical art (see section 4 sentence 1 number 2 TFG [8] and section 14 subsection 1 number $5 \mathrm{c}$ AMG [7]). He has to ensure that the eligibility of the donor complies with the state of the medical art and technology (see section 5 subsection 1 TFG). This includes the knowledge of the epidemiological situation in the blood establishment as well as in the zone of attraction of the blood establishment.

In Germany, the Robert Koch-Institut (RKI) is responsible for the establishment of concepts that prevent transmissible diseases (see section 4 German Infection Protection Act (Infektionss- chutzgesetz) [9]). The RKI observes carefully the prevalence and incidences for several infectious diseases and compiles yearly reports (see section 22 TFG [8]). The data has to be reported from laboratories, physicians and from blood establishments as well. This reporting from different sources enables the authorities (local health authority and the RKI) to evaluate the local situation. This evaluation of local data should also provide the medical head with information on the epidemiological situation of the environment of each of the blood establishments. Further data are available for each transmissible infection per district and per federal state (https://survstat.rki.de) [10] in a very detailed manner. The summary of all data is published on a regular basis $[9$, section 4 , subsection 2, number 4] in the Epidemiological Bulletin. Keeping the overview should be a general task for each medical head of a local donor recruitment area. The only partial overlap of the donor recruiting areas and the administrative regions is sometimes difficult to interpret. In the Epidemiological Bulletin, the RKI also defines 'risk groups'. In 2014 an amount of 1,904 newly diagnosed HIV cases out of 3,525 were found in MSM. Also 780 heterosexual transmissions were reported [11]. At least this defines MSM clearly as a major risk group, and even as a risk group with increasing incidences. There are also other risk groups defined such as heterosexuals with frequently changing sexual partners and intravenous drug abusers. The data of the RKI correlates well with the data of the European Centre for Disease Prevention and Control (ECDC) [12]. It should be noted that every member of such a risk group is at high risk for an infection. The same groups are also at high risk for transmission of the two other emerging blood-borne pathogens $\mathrm{HBV}$ and HCV. All three viruses face the same diagnostic issue, the window phase. This phase is caused by a delay between the infection and the time needed for a detectable immune reaction (anti$\mathrm{HIV}$ or anti-HCV) and/or the biometrical issue of the detection limit as it is defined in the ICH Q2R [13]: 'the limit of an individual analytical procedure is the lowest amount of analyte in a sample which can be detected but not necessarily quantitated as an exact value', which also implies that there is still a gap between this detection limit and ' 0 '. In addition, it should be noted that all assays in use - serological assays and nucleic acid testing (NAT) - are surrogate assays only. The detection of the 'infectivity' is either impossible or expansive and not suitable for routine screening at high numbers of donations.

6) The main objectives of the TFG and the said guidelines on hemotherapy of the German Medical Association are to contribute to the quality of donated blood and blood components and to the health protection of donors. The primary objective of the AMG is also to ensure the quality and safety of whole blood and blood components and to prevent the transmission of diseases. Therefore, there are several criteria for the deferral of donors who are even at a much lower risk for the transmission of an infection or disease [6, chapter 2.2.1]. For example, persons who stayed in UK and/or Northern Ireland between 1980 and 1996 have to be rejected for the risk of new variant Creutzfeld-Jakob disease. Moreover, persons with a sexual behavior which carries an increased 
risk for the transmission of pathogens like HBV, HCV or HIV, e.g. heterosexual persons with frequently changing sexual partners, MSM, and male and female prostitutes, have to be excluded.

Since the RKI defines these persons as risk groups, there is no reason to accept MSM as well as other members of potential risk groups as donors.

7) Especially in blood establishments running plasmapheresis, the average donation frequency is higher than in blood services offering blood donation only. It is well known, that the potential risk in donors with higher donation frequencies is much lower than in first-time donors. This is also reflected in the International Quality Plasma Program guidelines requiring at least two fully negative tested donations within 6 months [14]. The benefit of permanent donors compared to single-time donors (or first-time donors) for the product safety is obvious. Despite of all these measures, the remaining risk is still present [15]. The major issue is not the positively detected donor who is clearly identified. The real issue is the donor tested false-negative [16]. Donors giving dishonest responses in the donor questionnaire or in the medical investigation are the main reason for this problem, especially in case of $\mathrm{HBV}$ and HCV, [17, 18]. In 2011, it was shown by Jahn et al. [19] that either homo- or bisexual behaviors or piercing or tattoos could be the origin of these infections. A differentiating donor acceptance by product (virus inactivation possible or not) would not lead to any new arguments despite of the available inactivation methods for cellular products. In blood or platelet donations, one unit is given (if the plasma is not used for fractionation) to a maximum of 3 patients. In plasma (for fractionation) the residual risk is defined by the pool size, the number of different products made from a pool and the number of patients receiving products from a pool [15]. Both risks are not comparable and acceptable neither for the blood establishment nor for the patient receiving those products.

Also an ethical aspect should be taken into account. There is still a medical risk for the donor [20-22]. It is also unethical to discard the donation or to use it for quality control issues. Approaches established in other countries suggesting that the sexual behavior would be changed within a given time (e.g. 5 years in Canada) does not solve the issue $[23,24]$.

These main aspects demonstrate that there might be strong arguments which lead to differences between the Member States' legislation. Therefore, the conclusion is simple: It is not a matter of discrimination but of blood safety.

\section{References}

1 Judgement of 29 April 2015 in Case C-528/13 (Geoffrey Léger v Ministre des Affaires sociales, de la Santé et des Droits des femmes, Établissement français du sang).

2 Treaty on the Functioning of the European Union (in the consolidated version of the information of $26 \mathrm{Oc}$ tober 2012 (OJ EU No C 326/47).

3 Press Release of the Court of Justice of the European Union No 111/14 of 17 July 2014.

4 Ministre des Affaires sociales, de la Santé et des Droits des femmes, établissement français du sang: Marisol TOURAINE met fin à l'exclusion du don du sang en raison de l'orientation sexuelle. www.social-sante.gouv. $f r /$ actualite-presse, $42 /$ communiques, 2322/marisol-tourainemet-fin-a-l,18158.html (last accessed January 4, 2016).

5 German Federal Parliament (Deutscher Bundestag), stenographic protocol, 102th Meeting, Mai 6, 2015. Parliament Minutes 18/102, page 9772.

6 Richtlinien zur Gewinnung von Blut und Blutbestandteilen und zur Anwendung von Blutprodukten (Hämotherapie) gemäß $\$ \$ 12$ und 18 des Transfusionsgesetzes (TFG) (Änderungen und Ergänzungen 2010) vom 4. Mai 2010. . Bundesanzeiger 2010;101a:2389).

7 Gesetz über den Verkehr mit Arzneimitteln (AMG) in der Fassung vom 12. Dezember 2005. BGBl. I p. 3394, zuletzt geändert durch Gesetz vom 10. Dezember 2015, BGBl. I 2210.

8 Gesetz zur Regelung des Transfusionswesens (TFG) in der Fassung vom 28. August 2007. BGBl. I p. 2169), zuletzt geändert am 17. Juli 2009, BGBl. I p. 1990.

9 Gesetz zur Verhütung und Bekämpfung von Infektionskrankheiten beim Menschen (IfSG) vom 20. Juli 2000. BGBl. I S. 1045, zuletzt geändert durch Verordnung vom 31. August 2015. BGBl. I S. 1474.
10 Robert Koch-Institut: SurvStat@ RKI 2.0. Web-basierte Abfrage der Meldedaten gemäß Infektionsschutzgesetz (IfSG). https://survstat.rki.de (last accessed January 4, 2016).

11 Robert Koch-Institut: Aktuelle Statistik meldepflichtiger Infektionskrankheiten. Epidemiol Bull 2015;32: 317-320. www.rki.de/DE/Content/Infekt/EpidBull/ Archiv/2015/Ausgaben/32_15.pdf?_blob= publicationFile (last accessed January 4, 2016).

12 European Centre for Disease Prevention and Control, WHO Regional Office for Europe: HIV/AIDS Surveillance in Europe. 2013. Geneva, WHO, 2014. http:// ecdc.europa.eu/en/publications/Publications/hiv-aidssurveillance-report-Europe-2013.pdf (last accessed January 4,2016 ).

13 ICH Expert Working Group: ICH Harmonised Tripartite Guideline. Validation of Analytical Procedures: Text and Methodology Q2(R1). 2005. www.ich.org/ fileadmin/Public_Web_Site/ICH_Products/Guidelines/ Quality/Q2_R1/Step4/Q2_R1_Guideline.pdf (last accessed January 4, 2016

14 PPTA: International Quality Plasma Program (IQPP). www.pptaglobal.org/safety-quality/standards/iqpp (last accessed January 4, 2016).

15 George M: Plasma Control Europe Seminar. Vienna, Austria, March 10, 2005.

16 Abel U, Kießig ST: Modellrechnungen zum HIVScreening bei Blut- und Plasmaspendern mit der Kombination zweier Suchtests: Teststrategien, Validität. Kosten und Nutzen. Infusther Transfusionsmed 1995; 22:175-184.
Kesby M, Sothern M: Blood, sex and trust: the limits of the population-based risk management paradigm. Health Place 2014;26:21-30.

18 Lee CK, Lee KC, Lin CK, Lee SS: Donors' perspectives on self-deferral of men having sex with men from blood donation. Transfusion 2013;53: 2441-2448.

19 Jahn D, Kießig ST, Krause K-P: Evaluation of epidemiological reports. 2. Where are the risk groups? Trends in data evaluations of the years 2006-09 and 2010-11. Transfus Med Hemother 2013;40(suppl 1):53. INF-P11.

20 Diekamp U, Gneißl J, Rabe A, Kießig ST: Donor hemovigilance during preparatory plasmapheresis. Transfus Med Hemother 2014;41:123-133.

21 Diekamp U, Gneißl J, Rabe A, Kießig ST: Donor hemovigilance with blood donation. Transfus Med Hemother 2015;42:181-192).

22 Burkhardt T, Dimanski B, Karl R, Sievert U, Karl A, Hübler C, Tonn T, Sopvinik I, Ertl H, Moog R: Donor vigilance data of a blood transfusion service: a multicenter analysis. Transfus Apher Sci 2015;53:180-184.

23 Canadian Blood Services: MSM Policy. www.blood.ca/ en/msm (last accessed January 4, 2016).

24 Germain M, Robillard P, Delage G, Goldman M: Allowing blood donation from men who had sex with men more than 5 years ago: a model to evaluate the impact on transfusion safety in Canada. Vox Sang 2014;106:372-375. 